\title{
Dinoflagellate cysts and palynofacies across the Cretaceous-Paleogene boundary interval of the Vrancea Nappe (Eastern Carpathians, Romania)
}

\author{
Daniel ȚABĂRĂ $\breve{1}^{1, *}$ and Hamid SLIMANI ${ }^{2}$ \\ 1 "Al. I. Cuza" University of laşi, Department of Geology, 20A Carol I Blv., 700505 laşi, Romania \\ 2 University Mohammed V of Rabat, Scientific Institute, Laboratory of Geology and Remote Sensing, URAC 46, \\ Avenue Ibn Batouta, P.B. 703, 10106 Rabat-Agdal, Morocco
}

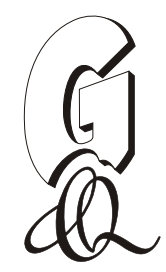

\begin{abstract}
Țabără, D., Slimani, H., 2017. Dinoflagellate cysts and palynofacies across the Cretaceous-Paleogene boundary interval of the Vrancea Nappe (Eastern Carpathians, Romania). Geological Quarterly, 61 (1): 39-52, doi: 10.7306/gq.1302

A palynological study of uppermost Maastrichtian to Lower Paleocene deposits from a stratigraphic section of the Vrancea Nappe (Eastern Carpathians), reveals the presence of diverse and well-preserved dinoflagellate cyst assemblages. The biostratigraphic interpretation of these dinocyst assemblages suggests that (1) the Cretaceous-Paleogene boundary lies within a $\sim 8 \mathrm{~m}$ thick sedimentary interval, between the Lepşa Formation (uppermost Maastrichtian) and Putna-Piatra Uscată Formation (Lower Danian), based on the Last Appearance Datum of latest Maastrichtian markers such as Pterodinium cretaceum and Palynodinium cf. grallator and on the First Appearance Datum of Danian markers such as Senoniasphaera inornata, Xenicodinium lubricum, Tectatodinium rugulatum and Eisenackia circumtabulata, and (2) a discontinuity between the two formations. The palynofacies analysis from this geological section indicates an abundance of continental organic matter (mainly opaque phytoclasts), deposited in a distal setting of the sedimentary basin. The occurrences in the palynological assemblage of some oceanic dinocyst taxa such as Impagidinium and Pterodinium suggest the same depositional environment for the geological formations analysed.
\end{abstract}

Key words: Vrancea Nappe, dinoflagellate cyst biostratigraphy, palynofacies, Cretaceous-Paleogene boundary interval.

\section{INTRODUCTION}

The Cretaceous-Paleogene ( $\mathrm{K}-\mathrm{Pg})$ boundary is recognized as representing one of the greatest mass extinction events in the last $500 \mathrm{Ma}$. The impact on the Earth of a large asteroid (Alvarez et al., 1980), intense volcanic activity, sea level fluctuations and climatic changes (Courtillot et al., 1986; Courtillot, 1990) are presently recognized as the causes of the global mass extinctions of most marine and terrestrial biota at the end of the Cretaceous. Among these causes, the Chicxulub impact in northern Yucatan (southern Mexico) is widely accepted as the primary cause for this Cretaceous-Paleogene extinction event $(65 \mathrm{Ma})$ while the Deccan volcanic activity in western India is also considered to be a principal cause (Keller, 2008; Keller et al., 2009).

In contrast to the terrestrial fauna (dinosaurs), as well as most aquatic organisms (calcareous planktonic foraminifera, nannoplankton, etc), organic-walled dinoflagellate cyst taxa did not undergo a mass extinction across the K-Pg boundary (Benson, 1976; Hansen, 1977; De Coninck and Smit, 1982;

\section{* Corresponding author, e-mail: dan.tabara@yahoo.com}

Received: January 15, 2016; accepted: April 21, 2016; first published online: July 14, 2016
Hultberg, 1985; Firth, 1987; Brinkhuis and Zachariasse, 1988; Moshkovitz and Habib, 1993; Habib et al., 1996; Gedl, 2004; Slimani et al., 2010). Biostratigraphical studies of this boundary based on the dinoflagellate cysts have been made at several Tethyan (Brinkhuis and Zachariasse, 1988; Gedl, 2004; Egger and Mohamed, 2010; Slimani et al., 2010, 2016; Mohamed et al., 2012, 2013; M'Hamdi et al., 2013; Mohamed and Wagreich, 2013; Slimani and Toufiq, 2013; Guédé et al., 2014) and boreal (Hansen, 1977; Moshkovitz and Habib, 1993; Brinkhuis and Schiøler, 1996; Habib et al., 1996; Slimani, 2001; Slimani et al., 2011) geological sections. Other $\mathrm{K}-\mathrm{Pg}$ sections are from New Zealand (Willumsen, 2004, 2011) in the Southern Hemisphere.

In the Moldavidian units of the Eastern Carpathians, where the geological section studied is located, the K-Pg transition was analysed from a palynostratigraphic point of view by Olaru (1978). The author noted that, in the Maastrichtian, the Normapolles group (primitive angiosperms) dominates the palynological assemblages $(65-70 \%)$, represented by the genera Complexipollis, Trudopollis, Plicapollis and Oculopollis. In addition to these palynomorphs, some species of spore (Leiotriletes tenuis, Verrucosisporites quintus, Baculatisporites primarius) and dinoflagellate cysts (e.g., Hystrichosphaeridium tubiferum, Cerodinium diebelii, Areoligera cf. senonensis) were noted. The Paleocene microflora cited from the Izvor Formation recorded a decline of the Normapolles group, the prevalent taxa comprising mono- and dicotyledonous angiosperms (e.g., Monocolpopollenites tranquillus, Tricolporopollenites wallensenensis, $T$. krutzschi, T. robustus), and some pteridophytes and gymno- 
sperms. The relative abundance of the dinoflagellate cysts decreases in the Paleocene, compared to that identified in Maastrichtian deposits, the cited species being Cerodinium diebelii, Achomosphaera ramulifera, Hystrichosphaeridium tubiferum and Oligosphaeridium complex (Olaru, 1978). Based on spores and pollen identified, Olaru (1978) inferred a cooling of the climate at the Maastrichtian-Paleocene boundary.

Other biostratigraphical studies of the K-Pg boundary were made based on calcareous nannofossil assemblages from the southwestern part of the Eastern Carpathians (Melinte and Jipa, 2005; Bojar et al., 2009) and on significant foraminiferal assemblages from the central and northern parts of the Moldavidian Units (lonesi, 1966, 1975; Ion et al., 1982; Guerrera et al., 2012).

The aim of this paper is to describe the dinoflagellate cyst biostratigraphy and palynofacies distribution across the $\mathrm{K}-\mathrm{Pg}$ boundary interval of the Vrancea Nappe (Cuejdiu-Runcu geological section, Eastern Carpathians).

\section{GEOLOGICAL SETTING AND STRATIGRAPHIC FRAMEWORK}

In the Eastern Carpathians, the Moldavide Nappe System is divided into the Inner Moldavides (i.e., Teleajen, Macla and Audia nappes), consisting mainly of Cretaceous strata, and the Outer Moldavides (i.e., Tarcău, Vrancea and the Subcarpa- thian nappes), comprising Cretaceous to earliest Miocene flysch deposits (Săndulescu, 1984; Grasu et al., 1988).

The Vrancea Nappe is structurally interposed between the Tarcău and Subcarpathian nappes and crops out in several tectonic half-windows, including the Bistrița Half-window. The geological cross-section analysed in this paper is located in this tectonic half-window (Fig. 1), more specifically at the confluence of the Cuejdiu and Runcu rivers (8 km NW of the city of Piatra Neamţ).

This geological section has been previously described, from the lithological and biostratigraphic point of view, by Grasu et al. (1988) and Guerrera et al. (2012). The sedimentary succession identified along the Cuejdiu and Runcu rivers is approximately $900 \mathrm{~m}$ thick, the lower part being assigned to the Sărata Formation of Early Cretaceous to Late Campanian age (Guerrera et al., 2012).

The Sărata Formation is subdivided into three lithological members: Lower Member (a succession of black shales with turbiditic arenites and conglomerate intercalations); Middle Member (silicified black shales with thin stratified calcarenites and breccias); and Upper Member (sandy marls with green-schists clasts). Upwards, the succession continues with the Lepşa Formation ( 115 m thick, Maastrichtian), which consists mainly of grey sandy marls with conglomerates with breccia intercalations. This formation is ended by a slumped body (15 $\mathrm{m}$ thick), described as an olistostrome, consisting of black shale from the Sărata Formation (Middle Member) deposited on a slope (Guerrera et al., 2012).

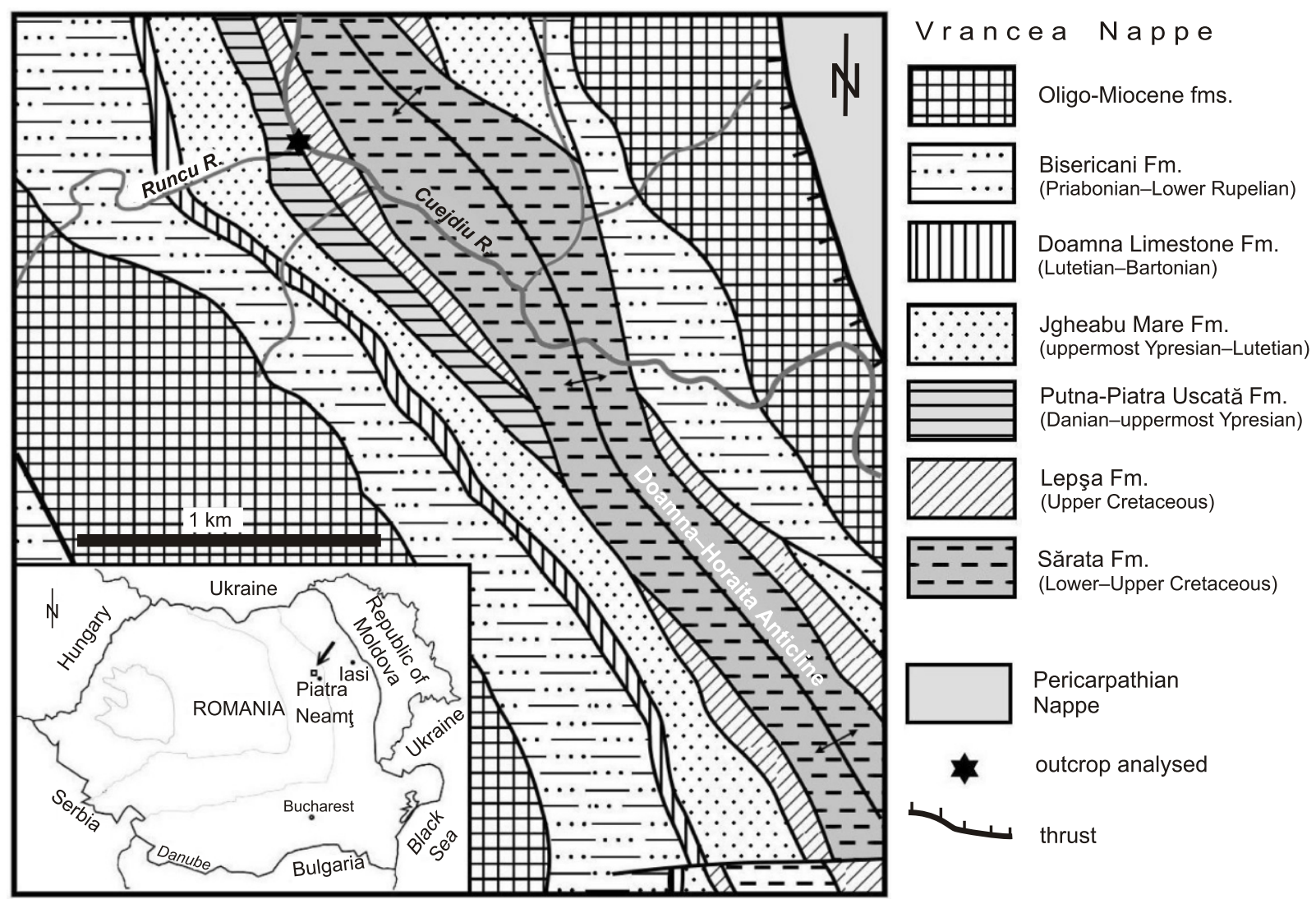

Fig. 1. Geological map of the studied area (after Micu, 1976, simplified); lithostratigraphic units and ages after Grasu et al. (1988), Amadori et al. (2012) and Guerrera et al. (2012) 
This olistostrome bed is overlain by the Putna-Piatra Uscată Formation (180 m thick; Lower Paleocene-uppermost Ypresian; Grasu et al., 1988; Guerrera et al., 2012), consisting of laminated black shales with limestone intercalations (up to 4-5 $\mathrm{m}$ thick), arenites and calcarenites. The geological section along the Runcu River ends with the Bisericani Formation (Priabonian-Lower Rupelian; Amadori et al., 2012).

Biostratigraphical data, based on planktonic foraminifera from the K-Pg boundary interval of the section studied, show that the Lepşa Formation (the middle part) contains Late Maastrichtian taxa such as Globotruncanita stuarti (De Lapparent), Abathomphalus mayaroensis (Bolli) and Racemiguembelina fructicosa (Egger) (Guerrera et al., 2012). The micropalaeontological content of the top of this formation is poor, and consists of scarce agglutinated foraminifers; this scarcity may be related to the Cretaceous-Paleogene extinction event. The lower part of the Putna-Piatra Uscată Formation also shows a poor micropalaeontological content, consisting of some earliest Paleocene small globigerinids, such as Subbotina cancellata Blow. According to these biostratigraphical data, Guerrera et al. (2012) placed the K-Pg boundary somewhere near the top of the Lepşa Formation.

\section{MATERIAL AND METHODS}

The K-Pg boundary section (coordinates: N 4659'44,04"; E $\left.26^{\circ} 16^{\prime} 33,45^{\prime \prime}\right)$ investigated in the present paper is located along the Runcu River, near the confluence of the Runcu and Cuejdiu rivers (Fig. 1). This section exposes $\sim 30 \mathrm{~m}$ thick of strata composed of the uppermost part of the Lepşa Formation (Upper Maastrichtian) and the lowermost part of the Putna-Piatra Uscată Formation (Lower Paleocene) (Fig. 2).

In total, six samples were analysed (Fig. 2): two samples (P140, P141) from the Lepşa Formation, one sample ( 142 ) from the olistostrome and three samples from the Putna-Piatra Uscată Formation. The palynological material studied shows low dinocyst diversity, but yielded the most dinocyst biostratigraphic markers, which are well-preserved and useful for age determinations of the samples analysed.

For palynological and palynofacies analysis, all samples were processed using standard palynological techniques (e.g., Batten, 1999). Approximately $50 \mathrm{~g}$ from each sediment sample was treated with $\mathrm{HCl}(37 \%)$ to remove carbonates and $\mathrm{HF}$ $(48 \%)$ to remove the silicate minerals. Denser particles were separated from the organic residue using $\mathrm{ZnCl}_{2}$ with a density of $2.0 \mathrm{~g} / \mathrm{cm}^{3}$. The palynological residues were mounted on microscopic slides with glycerine jelly. All samples yielded a palynological assemblage dominated by dinoflagellate cysts, while pollen grains, spores, bryophytes and acritarchs shows rare occurrences. Photomicrographs (Figs. 3 and 4) were taken with a digital Leica DFC420 camera mounted on an Leica DM1000 microscope. The taxonomy of the dinoflagellate cyst species follows Dinoflaj2 (Fensome et al., 2008) and Slimani et al. (2008). The age determination of deposits from the section analysed was obtained based on dinoflagellate cyst assemblages and their comparison with similar assemblages identified in many Maastrichtian to Danian biostratigraphically calibrated sections from the Northern Hemisphere (see above in the Introduction).

For the palynofacies analysis, the amount of kerogen in the palynological slides was analysed. At least $300-400$ organic particles $(>15 \mu \mathrm{m})$ were counted in each sample, these being included at the three main groups of kerogen constituents proposed by Tyson (1995), Mendonça Filho et al. (2002), Carvalho et al. (2006), and Țabără et al. (2015), namely: palynomorphs group (dinoflagellate cysts, spores, pollen and acritarchs); phytoclasts group which includes opaque and translucent organic particles derived from terrestrial plants (woody tissues, cuticles, membranes); and Amorphous Organic Matter (AOM) group which includes structureless organic components derived from phytoplankton or degraded higher plant debris.

In the marine environments, the proximal-distal trend is one of the principal controls on kerogen distribution. Several interpretive parameters, based on palynofacies observations, can be used for a detailed palaeoenvironmental analyses, namely: ratio of opaque to translucent phytoclasts (O:Trans; Steffen and Gorin, 1993; Carvalho et al., 2013) and the continental/marine palynomorphs ratio (C/M; Pellaton and Gorin, 2005). Also, onshore-offshore depositional environments and transgressive-regressive trends can be inferred based on a spore-pollen-microplankton (SPM) ternary diagram proposed by Federova (1977) and Duringer and Doubinger (1985).

The high relative abundance of translucent particles (e.g., woody tissues) in ancient marine deposits are known to indicate strong terrestrial influx, with deposition in nearshore proximal settings (e.g., fluvio-deltaic systems; Tyson, 1995; Carvalho et al., 2013). In contrast, opaque phytoclasts are derived from the oxidation of translucent particles, being more resistant palynomacerals that can be transported over a long distance without being further degraded. This O:Trans ratio tends to increase in the more distal facies. Large amounts of phytoclasts can also occur via turbidity currents in deep waters (Habib, 1982; Carvalho et al., 2013). The other parameter used, the $\mathrm{C} / \mathrm{M}$ ratio (calculated by taking the number of all terrestrial palynomorphs, divided by the number of dinoflagellate cysts), generally decreases offshore.

\section{RESULTS}

\section{PALYNOLOGICAL CONTENT}

The palynomorph assemblages from the $\mathrm{K}-\mathrm{Pg}$ section analysed here consist mainly of dinoflagellate cysts (83-100\% of the total palynomorphs), except for sample P140, in which a lower percentage $(61 \%)$ is recorded. A total of 52 dinoflagellate cyst species and subspecies have been recognized; most of the taxa recorded in the Upper Maastrichtian cross the K-Pg boundary and persist into the Danian. This aspect does not indicate a severe extinction of dinoflagellate species across the K-Pg boundary, in contrast to the mass extinction recorded in the planktonic foraminifer assemblages (Paul, 2005; Twitchett, 2006).

Lepşa Formation. The palynological assemblage identified in samples P140 and P141 (Fig. 2) contains dinocyst species such as Palynodinium cf. grallator, Pterodinum cretaceum, Deflandrea galeata, Manumiella seelandica, Muratodinium fimbriatum, Cerodinium diebelii, Rottnestia wetzelii subsp. wetzelii, Trithyrodinium evittii, Achomosphaera sagena, Palaeoperidinium pyrophorum, and Phelodinium magnificum (Table 1), commonly used to identify Upper Maastrichtian strata in many areas (see related references mentioned above in the Introduction). Rare Cretaceous reworked specimens such as Cannosphaeropsis utinensis have been found in sample P141. Among continental palynomorphs can be listed pteridophyte spores (Deltoidospora toralis, D. psilostomata, Gleicheniidites senonicus, Triplanosporites sp.), gymnosperms (Podocarpidites sp., Araucariacites sp., Cycadopites sp. and Ephedripites sp.) and early angiosperms (Normapolles). 


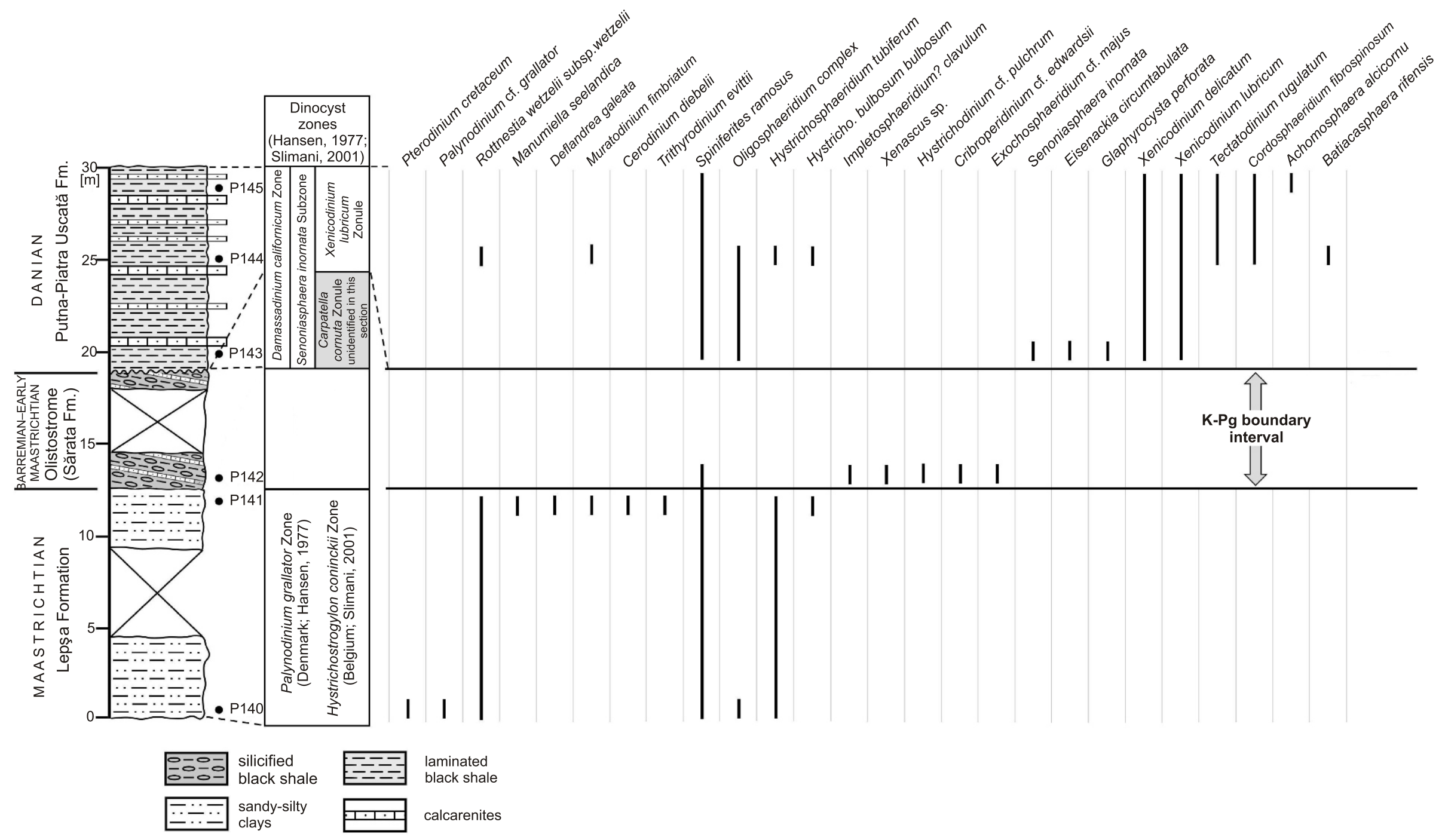

Fig. 2. A lithological log of the geological section analysed on the Runcu River and a range chart illustrating the stratigraphical occurrence of selected dinoflagellate cysts 

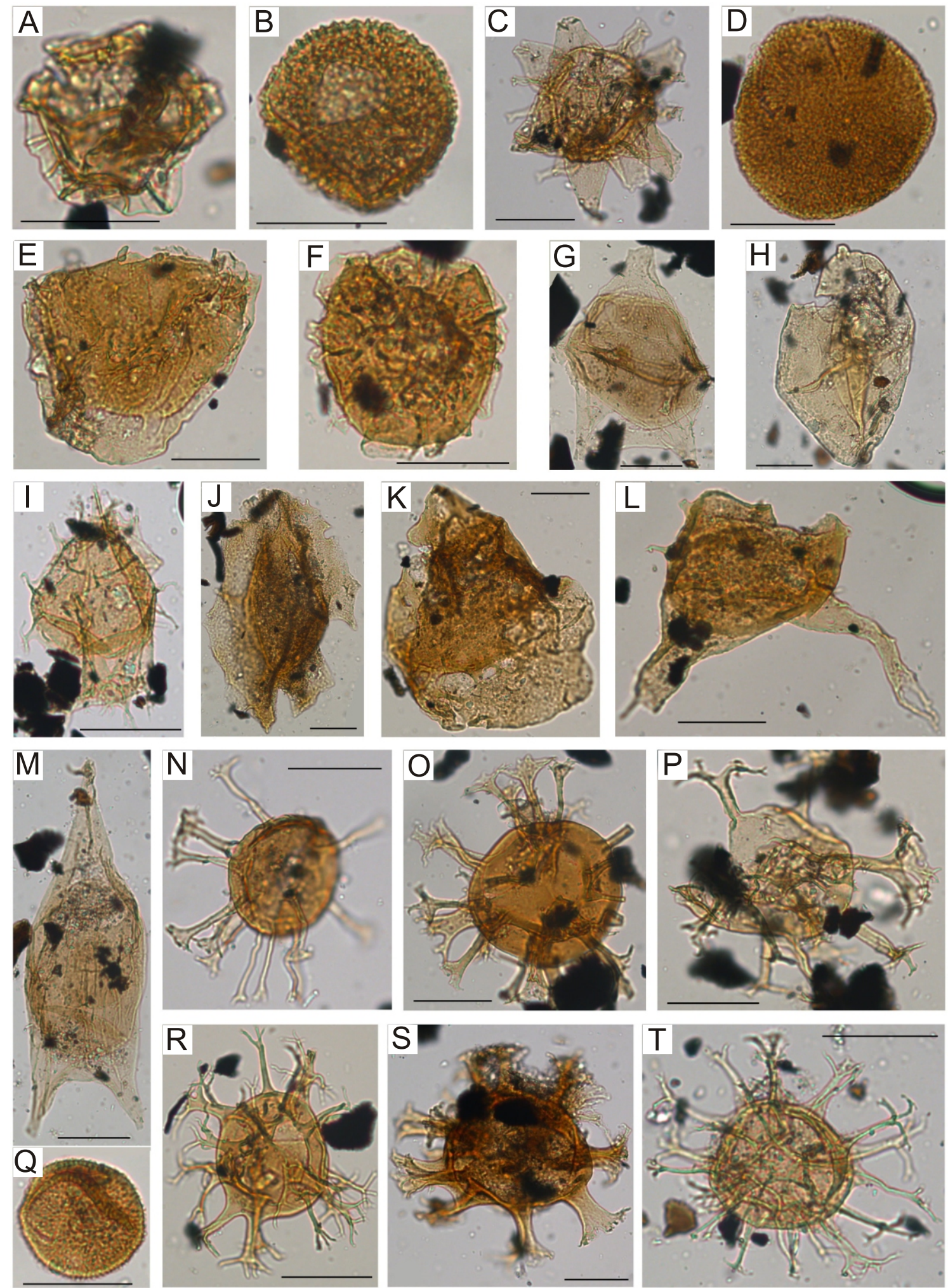

Fig. 3. Selected dinocyst species from Runcu section

A - Pterodinum cretaceum (sample P140); B - Xenicodinium lubricum (sample P143); C - Hystrichokolpoma bulbosum subsp. bulbosum (sample P144); D - Tectatodinium rugulatum (sample P145); E - Senoniasphaera inornata (sample P143); F - Eisenackia circumtabulata (sample P143); G - Deflandrea galeata (sample P141); H - Manumiella seelandica (sample P141); I - Rottnestia wetzelii subsp. wetzelii (sample P141); J - Muratodinium fimbriatum (sample P141); K Glaphyrocysta perforata (sample P143); L - Xenascus sp. (sample P142); M - Cerodinium diebelii (sample P141); N Hystrichosphaeridium tubiferum (sample P144); O - Achomosphaera alcicornu (sample P145); P - Oligosphaeridium complex (sample P140); Q - Xenicodinium delicatum (sample P145); R - Achomosphaera ramulifera (sample P144); S Cordosphaeridium fibrospinosum (sample P144); T - Spiniferites ramosus (sample P141); scale bar $30 \mu \mathrm{m}$ 

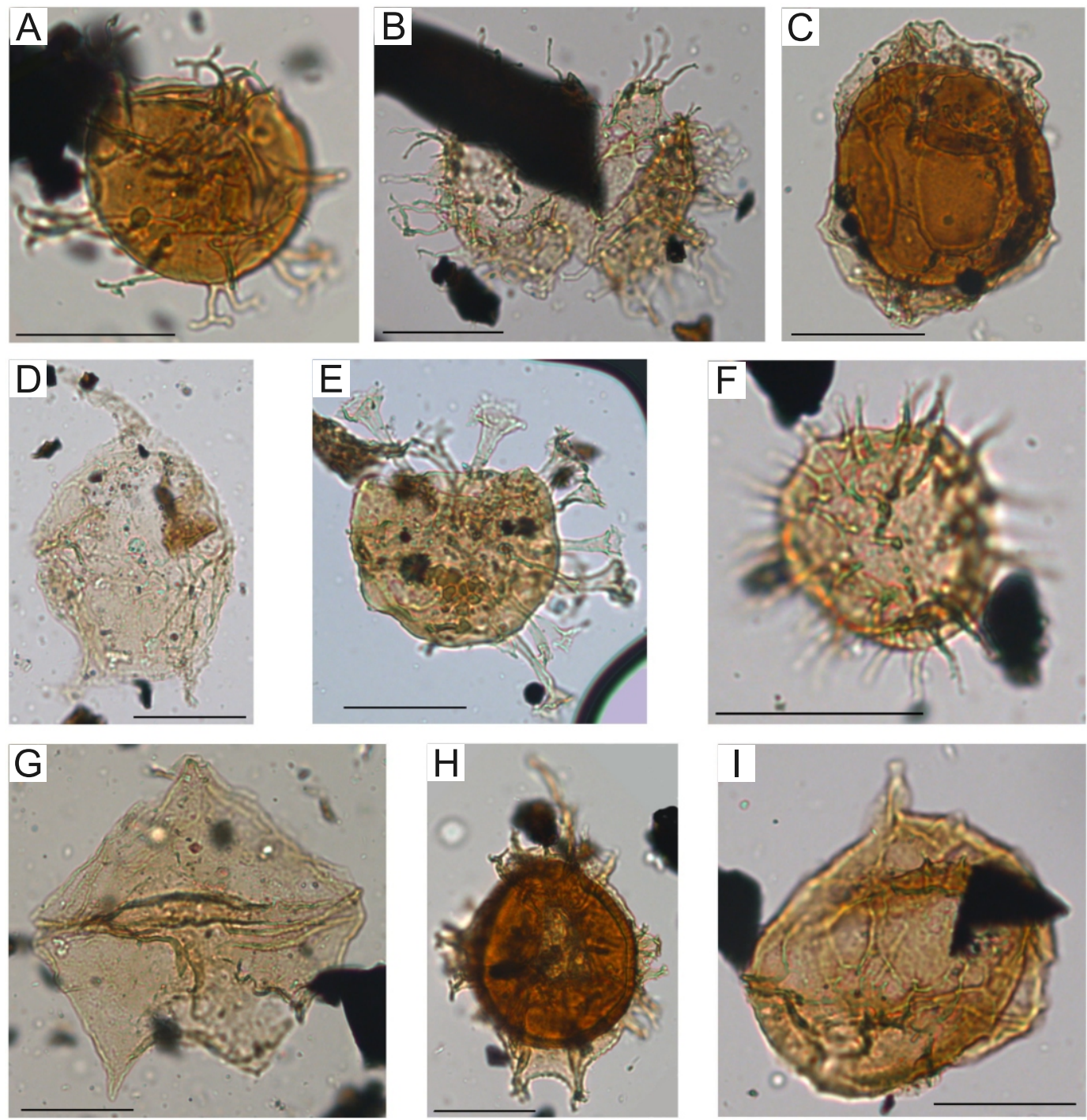

Fig. 4. Selected dinocyst species from Runcu section

A - Achomosphaera regiensis (sample P145); B - Areoligera senonensis (sample P143); C - Pentadinium sp. A (sample P144); D - Cerodinium speciosum (sample P141); E - Oligosphaeridium buciniferum (sample P142); F - Operculodinium corradinii (sample P143); G - Palaeoperidinium pyrophorum (sample P141); H - Spiniferella cornuta subsp. cornuta (sample P145); I - Cribroperidinium wetzelii (sample P143); scale bar $30 \mu \mathrm{m}$

From the olistostrome above the Lepşa Formation, a single sample (P142) was analysed. The dinoflagellate cyst assemblage is dominated by Spiniferites div. sp., and other taxa such as Cribroperidinium cf. edwardsii, Hystrichodinium cf. pulchrum, Oligosphaeridium buciniferum, Protoellipsodinium cf. clavulum, Xenascus sp. have been identified. Continental palynomorphs have a frequency of $12 \%$, and include some spores (Deltoidospora toralis, Baculatisporites sp.) and rare specimens of Normapolles pollen.

Putna-Piatra Uscată Formation. From the bottom of this formation, three samples were analysed (P143-P145; Fig. 2). The palynological content consists of a high frequency of dinocyst taxa (mainly Spiniferites group, and Xenicodinium div. sp.), together with species such as Achomosphaera ramulifera, A. regiensis, A. alcicornu, Batiacasphaera rifensis, Hafniasphaera septata, Impagidinium sp., Oligosphaeridium complex, Spiniferella cornuta subsp. cornuta, Cribroperidinium wetzelii, Eisenackia circumtabulata, Senoniasphaera inornata, Tectatodinium rugulatum, Xenicodinium delicatum and $X$. Iubricum
(Table 1). The spores identified in the samples analysed have a low frequency (some specimens of Baculatisporites sp., Deltoidospora sp. found in sample P145), and gymnosperm pollen is represented by Pinuspollenites sp. and Cycadopites $\mathrm{sp}$. (Table 1). An acritarch species (Micrhystridium fragile) occure in sample P145, while Normapolles pollen is poorly represented in samples $\mathrm{P} 143$ and $\mathrm{P} 145$

\section{PALYNOFACIES DATA}

The quantitative and qualitative analysis of organic particles present in all the samples analysed reveals a predominance of organic matter of continental origin. At the top of the Lepşa Formation (samples P140 and P141), the palynofacies consists of a large proportion of opaque phytoclasts (95-98\%), that belong to the inertinite group, and locally small amounts of woody tissues and cuticles can be identified. The palynomorph group is poorly represented $(1-2 \%)$, generally consisting of dinofla- 
gellate cysts and a lower frequency of continental palynomorphs (dominantly pteridophyte spores and gymnosperms). The AOM group has a rare occurrence, only some particles of gelified AOM (derived from degraded higher plant debris) being identified.

In the olistostrome (sample P142) identified in the geological section, the palynofacies is generally similar to that inferred from the Lepşa Formation (samples P140 and P141). The opaque phytoclasts show a high percentage (93-95\%), to which is added some small granular AOM particles (derived from phytoplankton degradation). The palynomorphs (1\%), are represented by various species of dinoflagellate, spores being rarely encountered.

The lower part of the Putna-Piatra Uscată Formation (samples P143-P145) comprises also a palynofacies dominated by opaque phytoclasts (98\%), some of these phytoclasts being small and rounded. Other phytoclasts such as woody tissues and some biodegraded cuticles are rarely identified. The palynomorphs $(1 \%)$ are mainly represented by dinoflagellate cysts, in some samples (P144) only phytoplankton species being determined.

\section{INTERPRETATION AND DISCUSSION}

\section{DINOFLAGELLATE CYST BIOSTRATIGRAPHY}

The stratigraphic distribution of dinoflagellate taxa in the Runcu section is shown in Table 1. The age determination in the geological section analysed is based on the First Appearance Datum (FAD) and Last Appearance Datum (LAD) of significant dinoflagellate species.

Latest Maastrichtian. The biostratigraphic interpretation of the dinocyst assemblages, based on the dinocyst bioevents, suggests an Late Maastrichtian age for the top of the Lepşa Formation. Among the species identified in this formation, an important marker taxon is Pterodinum cretaceum, which has been named differently (see Slimani et al., 2010: pp. 104), having the LAD in the latest Maastrichtian (Schirler and Wilson, 1993; Roncaglia and Corradini, 1997a, b; Slimani, 2001; Torricelli and Amore, 2003; Slimani et al., 2008, 2010, 2011, 2016; Slimani and Toufiq, 2013; M'Hamdi et al., 2013; Guédé et al., 2014). This species is recorded in a single sample (P140). Also, the species Palynodinium cf. grallator, which is another marker for the latest Maastrichtian, is observed in sample $\mathrm{P} 140$, the LAD of this species being frequently recorded at top of the Upper Maastrichtian in different geological sections from northern higher latitudes (Hansen, 1977; Schiřler and Wilson, 1993; Habib et al., 1996; Schiøler et al., 1997; Williams et al., 2004; Slimani et al., 2011), but rarely quoted in the lowermost Danian in low latitudes (Brinkhuis et al., 1998; Gedl, 2004; Slimani et al., 2010; Mohamed et al., 2012; M'Hamdi et al., 2013). Manumiella seelandica, Deflandrea galeata and Muratodinium fimbriatum have been identified in the top of the Lepşa Formation (P141 sample). These species have their FAD's in the Upper Maastrichtian, but may persist up to the Danian in Morocco (Slimani et al., 2010, Guédé et al., 2014), Tunisia (M'Hamdi et al., 2013), the Czech Carpathians (Gedl, 2004) and elsewhere. Another species, such as Rottnestia wetzelii subsp. wetzelii, which was rarely quoted at the $\mathrm{K}-\mathrm{Pg}$ boundary from the Northern Hemisphere, was identified from the Upper Maastrichtian of Austria (Mohamed and Wagreich, 2013), and considered as a marker for the Late Maastrichtian in Greenland (Nøhr-Hansen, 2012). In the study section of the Runcu River, this species has been identified in almost all sam- ples analysed (above and below the K-Pg boundary). The species that have been recorded both from the top of the Lepşa Formation and from the lower part of the Putna-Piatra Uscată Formation include Spiniferites ramosus (frequent), Oligosphaeridium complex, Hystrichosphaeridium tubiferum (rare in the Upper Maastrichtian and frequent in Danian), Achomosphaera ramulifera, Hystrichokolpoma bulbosum subsp. bulbosum.

In summary, the FAD's and LAD's of all species observed in samples P140 and P141 suggest a latest Maastrichtian age for the uppermost part of the Lepşa Formation, which can be correlated with Hansen's (1977) Palynodinium grallator and Slimani's (2001) Hystrichostrogylon coninckii zones, based on the last occurrence of Palynodinium cf. grallator.

The dinoflagellate species identified in the olistostrome above the Lepşa Formation indicate a Barremian-Early Maastrichtian age of these deposits, the genus Xenascus being an important marker (Williams et al., 1993). Another taxon identified in sample P142 is Hystrichodinium cf. pulchrum, quoted from Campanian-Lower Maastrichtian deposits of the Outer Western Carpathians (Skupien and Mohamed, 2008), the LAD of this species being known in the Early Maastrichtian. Other Cretaceous dinoflagellate cysts taxa are observed in this olistostrome such as Impletosphaeridium? clavulum, Hystrichosphaeridium salpingophorum, Oligosphaeridium buciniferum, and Cribroperidinium cf. edwardsii (quoted from the Middle Member of the Audia Formation; Tabără, 2014). The marker taxa previously mentioned indicate a Barremian-Lower Maastrichtian age of the sedimentary deposits analysed from the lower part of the olistostrome. The slumping of these deposits suggests significant tectonic activity at the Cretaceous-Paleogene transition, sourcing Barremian-Lower Maastrichtian materials from the Sărata Formation.

Early Danian. Dinoflagellate cysts such as Damassadinium californicum, Carpatella cornuta, Senoniasphaera inornata are global Danian index fossils, valuable for the identification of the K-Pg boundary (Drugg, 1967; Gedl, 2004; Williams et al., 2004; Slimani et al., 2010; Slimani and Toufiq, 2013; Mohamed and Wagreich, 2013; Mohamed et al., 2013; M'Hamdi et al., 2013; Guédé et al., 2014). Among these species, only Senoniasphaera inornata has been identified in the lower part of the Putna-Piatra Uscată Formation (sample P143). This occurrence suggests that the K-Pg boundary can be placed below the first appearance of this species and above the last appearance of the Maastrichtian species Pterodinium cretaceum and Palynodinium cf. grallator, within the interval between samples $\mathrm{P} 141$ and $\mathrm{P} 143$ (Fig. 2). The stratigraphic range (FAD and LAD) of Senoniasphaera inornata is restricted to the Early-Middle Danian interval (62.6-64.95 Ma; Hardenbol et al., 1998; Williams et al., 2004; Slimani et al., 2010).

Eisenackia circumtabulata is another important species for the identification of the $\mathrm{K}-\mathrm{Pg}$ boundary. Its FAD indicates the lowermost Danian in several biostratigraphically calibrated sections such as El Kef in Tunisia (Brinkhuis and Zachariasse, 1988) and Ouled Haddou in Morocco (Slimani et al., 2010; Slimani and Toufiq, 2013). In the section studied, this species first occurs in sample P143, at the same level as Senoniasphaera inornata.

The dinoflagellate species Xenicodinium lubricum and Tectatodinium rugulatum, which have well-documented FADs in the Lower Danian (Hansen, 1977; Hardenbol et al., 1998; Slimani, 2000, 2001), were recorded only in the Putna-Piatra Uscată Formation (samples P143-P145) and therefore confirm the position of the K-Pg boundary determined above, based on the LAD of Pterodinium cretaceum and Palynodinium cf. grallator, and the FAD of Senoniasphaera inornata. Their stratigraphic range in the section studied can be correlated with 
Distribution of palynomorph taxa in the Runcu section

\begin{tabular}{|c|c|c|c|c|c|c|}
\hline \multirow{2}{*}{$\begin{array}{c}\text { Age } \\
\text { Taxa/Samples }\end{array}$} & \multicolumn{2}{|c|}{ Maastr. } & \multirow{2}{*}{$\frac{\text { B-M }}{\text { P142 }}$} & \multicolumn{3}{|c|}{ Danian } \\
\hline & $\mathrm{P} 140$ & $\mathrm{P} 141$ & & P143 & P144 & $\mathrm{P} 145$ \\
\hline \multicolumn{7}{|c|}{ Dinoflagellate cysts } \\
\hline Palynodinium cf. grallator & 2 & & & & & \\
\hline Pterodinium cingulatum & 1 & & & & & \\
\hline Pterodinum cretaceum & 3 & & & & & \\
\hline Achomosphaera sagena & 1 & 3 & & & & \\
\hline Cannosphaeropsis utinensis (reworked) & & 1 & & & & \\
\hline Cerodinium diebelii & & 9 & & & & \\
\hline Cerodinium speciosum & & 2 & & & & \\
\hline Deflandrea galeata & & 1 & & & & \\
\hline Manumiella seelandica & & 2 & & & & \\
\hline Palaeoperidinium pyrophorum & & 2 & & & & \\
\hline Phelodinium magnificum & & 1 & & & & \\
\hline Tanyosphaeridium xanthiopyxides & & 1 & & & & \\
\hline Trithyrodinium evittii & & 2 & & & & \\
\hline Achomosphaera ramulifera & 1 & 1 & & 3 & 5 & 1 \\
\hline Areoligera senonensis & & 1 & & 1 & & \\
\hline Fibrocysta axialis & 1 & & & & 2 & \\
\hline Hafniasphaera septata & 1 & & & & 6 & 2 \\
\hline Hystricho. bulbosum subsp. bulbosum & & 1 & & & 1 & \\
\hline Hystrichosphaeridium tubiferum & 1 & 2 & & & 5 & \\
\hline Impagidinium sp. & 1 & 4 & & 1 & 12 & 2 \\
\hline Muratodinium fimbriatum & & 4 & & & 1 & \\
\hline Oligosphaeridium complex & 2 & & & 1 & 3 & \\
\hline Operculodinium centrocarpum & & 1 & & & & 1 \\
\hline Rottnestia wetzelii subsp. wetzelii & 2 & 3 & & & 3 & \\
\hline Spiniferella cornuta subsp. cornuta & & 1 & & & 2 & 2 \\
\hline Spiniferites multibrevis & & 1 & 2 & 1 & 1 & 2 \\
\hline Spiniferites ramosus & 6 & 10 & 4 & 5 & 6 & 4 \\
\hline Spiniferites sp. & 3 & 6 & 11 & 13 & 12 & 8 \\
\hline Cribroperidinium cf. edwardsii & & & 1 & & & \\
\hline Exochosphaeridium cf. majus & & & 1 & & & \\
\hline Hystrichodinium cf. pulchrum & & & 1 & & & \\
\hline Hystrichospha. salpingophorum & & & 1 & & & \\
\hline Impletosphaeridium? clavulum & & & 2 & & & \\
\hline Oligosphaeridium buciniferum & & & 1 & & & \\
\hline Protoellipsodinium cf. clavulum & & & 1 & & & \\
\hline Senoniasphaera cf. rotundata & & & 1 & & & \\
\hline Xenascus sp. & & & 1 & & & \\
\hline Cordosphaeridium exilimurum & & & & 1 & & \\
\hline Cribroperidinium wetzelii & & & & 3 & & \\
\hline Eisenackia circumtabulata & & & & 1 & & \\
\hline Glaphyrocysta perforata & & & & 1 & & \\
\hline Lingulodinium sp. & & & & 2 & & \\
\hline Operculodinium corradinii & & & & 1 & & \\
\hline Senoniasphaera inornata & & & & 2 & & \\
\hline Achomosphaera regiensis & & & & 4 & 2 & 4 \\
\hline Pentadinium sp. A & & & & 4 & 8 & 1 \\
\hline Xenicodinium delicatum & & & & 1 & & 3 \\
\hline Xenicodinium lubricum & & & & 10 & 4 & 3 \\
\hline Batiacasphaera rifensis & & & & & 2 & \\
\hline Hystrichosphaeridium recurvatum & & & & & 1 & \\
\hline Impletosphaeridium sp. & & & & & 1 & \\
\hline Kleithriasphaeridium truncatum & & & & & 1 & \\
\hline
\end{tabular}


Tab. 1 cont.

\begin{tabular}{|c|c|c|c|c|c|c|}
\hline Age & \multicolumn{2}{|c|}{ Maastr. } & B-M & \multicolumn{3}{|c|}{ Danian } \\
\hline Taxa/Samples & P140 & P141 & $\mathrm{P} 142$ & P143 & P144 & P145 \\
\hline Oligosphaeridium pulcherrimum & & & & & 3 & \\
\hline Cordosphaeridium fibrospinosum & & & & & 1 & 1 \\
\hline Tectatodinium rugulatum & & & & & 1 & 4 \\
\hline Achomosphaera alcicornu & & & & & & 1 \\
\hline Kleithriasphaeridium cf. loffrense & & & & & & 1 \\
\hline Palaeocystodinium cf. golzowense & & & & & & 1 \\
\hline Systematophora sp. & & & & & & 1 \\
\hline \multicolumn{7}{|c|}{ Acritarcha } \\
\hline Micrhystridium fragile & & & & & & 1 \\
\hline \multicolumn{7}{|c|}{ Pteridophyta } \\
\hline Triplanosporites sp. & 2 & & & & & \\
\hline Deltoidospora psilostomata & 1 & & & & & \\
\hline Deltoidospora toralis & & 1 & 1 & & & \\
\hline Deltoidospora sp. & 5 & & & & & 1 \\
\hline Gleicheniidites senonicus & & 1 & & & & \\
\hline Baculatisporites sp. & & & 1 & & & 1 \\
\hline \multicolumn{7}{|c|}{ Gymnospermatophyta } \\
\hline Araucariacites sp. & & 1 & & & & \\
\hline Podocarpidites sp. & & 1 & & & & \\
\hline Ephedripites sp. & & 1 & 1 & & & \\
\hline Cycadopites sp. & & 1 & & 1 & & \\
\hline Pinuspollenites sp. & & & & & & 1 \\
\hline
\end{tabular}

The arrangement of taxa is according to the first occurrence, and key dinoflagellate species are shaded. Maastr. - Maastrichtian; B-M - Barremian-Lower Maastrichtian

Xenicodinium lubricum Zonule (upper part of the Damassadinium californicum Zone; Hansen, 1977), established in Lower Danian limestones in Denmark. Also, both species (X. lubricum and $T$. rugulatum) were recorded in Danian deposits in the Caspian Depression by Vasilyeva and Musatov (2012). Carpatella cornuta, the zonal species of the lowermost Danian Carpatella cornuta Zonule (lower part of the Damassadinium californicum Zone; Hansen, 1977) is not recorded in the section studied. The absence of this species might be related to its extreme scarcity or to unfavorable environmental conditions.

The FADs of Achomosphaera alcicornu and Xenicodinium delicatum are also indicative of the Lower Danian (Hultberg, 1985; Slimani, 2001; Slimani et al., 2010, 2011; Slimani and Toufiq, 2013; M'Hamdi et al., 2013). Their occurrence in the section studied supports the Danian age of the interval analysed in the Putna-Piatra Uscată Formation. Other species, previously recorded in Maastrichtian and Danian strata, were identified only in the Putna-Piatra Uscată Formation. Among these taxa are Batiacasphaera rifensis, Cordosphaeridium fibrospinosum, Cribroperidinium wetzelii, Glaphyrocysta perforata and Operculodinium corradinii.

In summary, all these Maastrichtian and Danian dinocyst event markers suggest that the K-Pg boundary may be placed somewhere between the latest sample analysed (P141) at the top of the Lepşa Formation and the earliest sample analysed (P143) of the base of the Putna-Piatra Uscată Formation. The presence of the Barremian-Lower Maastrichtian olistostrome (devoid of dinocyst markers of the uppermost Maastrichtian-lowermost Danian boundary interval) between the Lepşa and Putna-Piatra Uscată formations prevent precise localization of the K-Pg boundary in the study section. We also did not observe, as indicated in other studies (see above in the Introduction), any mass extinction of dinocysts in the K-Pg boundary interval of the Runcu section. However, the micropalaeontological content (foraminifers) is poor at the top of the Lepşa Formation (Guerrera et al., 2012) and may suggest consequently a mass extinction of this group close to the K-Pg boundary interval.

The Maastrichtian dinoflagellate assemblage in the section studied shows more similarities with Tethyan assemblages (De Coninck and Smit, 1982; Brinkhuis and Zachariasse, 1988; Slimani et al., 2010, 2016; Mohamed et al., 2012; M'Hamdi et al., 2013) than with Boreal assemblages (Hansen, 1977; Hultberg, 1985; Schiřler and Wilson, 1993; Slimani, 2001; Slimani et al., 2011). Compared to the other sections from the Tethyan realm, shows also more similarities with the Maastrichtian dinocysts assemblage from southeastern Czech Republic (Carpathian domain; Gedl, 2004) than with the assemblage from south-east Poland (western part of the East European Platform; Machalski et al., 2016), which was considered to be characteristic of Boreal province, due to the high abundance of the cold water taxon, such as Palynodinium grallator. The most important differences observed, compared to the assemblage quoted from the Czech Carpathians, consists in the fact that the Palynodinium grallator disappears earlier (uppermost Maastrichtian) in the studied section, probably due to different palaeoenvironmental conditions. However, the Danian assemblage is similar to many other assemblages quoted from world-wide, identified both at low and high latitude. 


\section{PALAEOENVIRONMENTAL RECONSTRUCTION}

Palynofacies analyses as described by Tyson (1995) comprise an important tool in sedimentology for reconstructing depositional environments. The sedimentary organic matter (also called kerogen) recorded from the formations discussed herein includes a large proportion of continental material, with phytoclasts, pollen grain and spores, as well as a small amount of marine material composed of dinoflagellate cysts and granular AOM.

The kerogen analysed from the Lepşa Formation is composed mainly of opaque phytoclasts that are derived primarily from the oxidation of plant tissue, which was transported over a prolonged period of time (Carvalho et al., 2013). The O:Trans ratio, calculated based on palynofacies data obtained from this geological formation, shows a high value, suggesting a more distal setting, at least outer shelf zone. The same environment is also indicated by the $\mathrm{C} / \mathrm{M}$ ratio, the latter having a lower value in sample P141 (dinoflagellate cysts prevailing) and slightly higher in sample P140 due to sporomorphs derived from the continental landmass. The occurrences in the Lepşa Formation of some oceanic dinocysts such as Impagidinium and Pterodinium supports the same palaeoenvironmental interpretation. Oceanic dinoflagellate taxa were also recorded in Maastrichtian-Danian deposits from the Czech Carpathians, showing a high frequency in hemipelagic deposits (Gedl, 2004). Nevertheless, the palynological assemblage from the Lepşa Formation also contains some species of the Spiniferites group, which indicates inner-outer neritic environments (Sluijs et al., 2005). This offshore depositional environment inferred for the Lepşa Formation is also suggested by plotting the frequencies of palynomorphs in an SPM ternary diagram (Fig. 5).

The palynofacies recorded from the olistostrome above the Lepşa Formation is generally similar to that inferred from the Lepşa Formation. The organic matter is characterized by a high percentage of opaque phytoclasts and a small amount of granular AOM and dinoflagellate cysts. The O:Trans ratio, as well as the $\mathrm{C} / \mathrm{M}$ ratio, indicate a more distal facies for these deposits.

The depositional environment of the Putna-Piatra Uscată Formation (lower part) is very similar to that inferred from the Lepşa Formation. The palynofacies of this formation is dominated by opaque phytoclasts $(98 \%)$, these organic particles of-

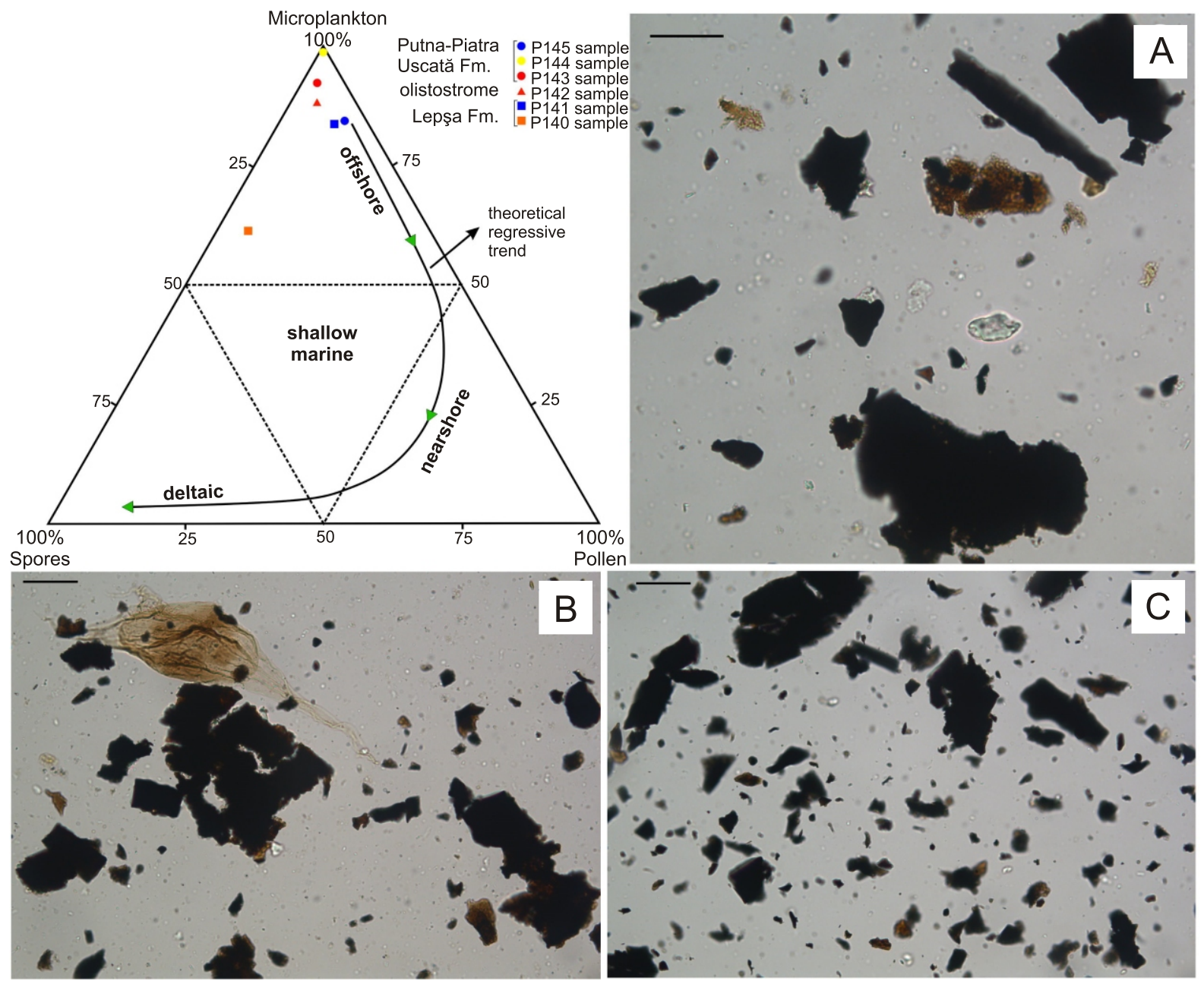

Fig. 5. Spore-pollen-microplankton ternary plot (Federova, 1977; Duringer and Doubinger, 1985) indicating an offshore depositional environment for the deposits analysed

Transmitted light microphotographs of the palynofacies from the samples analysed (scale bar $30 \mu \mathrm{m}$ ): $\mathbf{A}$ - opaque phytoclasts of various shapes and sizes, with small amounts of translucent phytoclasts (olistostrome, sample P142); B - a mixed assemblage of opaque phytoclasts and dinocysts (Lepşa Formation, sample P141); C - palynofacies dominated by small opaque phytoclasts (Putna-Piatra Uscată Formation, sample P143) 
ten having small dimensions and rounded shapes (Fig. 5C), as a result of prolonged transport in distal environments (Steffen and Gorin, 1993). The dominance of dinoflagellate cysts, compared to the spores-pollen assemblage (Fig. 5, ternary diagram), is indicative of deposition in an offshore environment. Moreover, the occurrences of oceanic dinocysts such as Impagidinium (locally with higher proportions; $15 \%$ in sample P144 sample), suggest the same environmental interpretation for the Putna-Piatra Uscată Formation.

\section{CONCLUSIONS}

This paper describes biostratigraphical data from the K-Pg boundary interval of the Outer Moldavides (Vrancea Nappe), inferred based on dinoflagellate cyst bioevents, as well as on palynofacies analysis across this boundary interval. The main conclusions are the following:

- the dinocyst assemblage identified in the top of the Lepşa Formation indicates a latest Maastrichtian age. Important biostratigraphic event markers for this age are the LADs of Pterodinium cretaceum and Palynodinium cf. grallator. This interval can be correlated with the latest Maastrichtian Palynodinium grallator Zone of Hansen (1977) and the Hystrichostrogylon coninckii Zone of Slimani (2001);

- the occurrence of the dinoflagellate cysts Xenascus $\mathrm{sp}$. and Hystrichodinium cf. pulchrum may indicate a Barremian to Early Maastrichtian age for the olistostrome disposed above the Lepşa Formation. This slumping event may suggest significant tectonic activity at the Cretaceous-Paleogene transition;

- the dinocyst assemblage recorded in the Putna-Piatra Uscată Formation can be correlated with the Lower Danian Xenicodinium Iubricum Zonule of Hansen (1977). The K-Pg boundary lies somewhere within the $\sim 8 \mathrm{~m}$ thick strata interval between the top of the Lepşa Formation (sample P141) and the base of the Putna-Piatra Uscată Formation (sample P143), namely between the last occurrence of the Maastrichtian dinocyst markers, such as Pterodinium cretaceum and Palynodinium cf. grallator, and the first occurrence of Danian dinocyst markers such as Senoniasphaera inornata, Xenicodinium lubricum, Tectatodinium rugulatum and Eisenackia circumtabulata. Unfortunately, the presence of the olistostrome between the Lepşa and Putna-Piatra Uscată formations does not allow a more accurate localization of the K-Pg boundary in the section studied;

- the Maastrichtian dinoflagellate assemblage from the Runcu section shows more similarities with Tethyan assemblages, but compared with other assemblages from the same palaeogeographical area (the Western Carpathians and the western part of the East European Platform), some differences in the last appearance and abundance of cold water taxa (e.g., Palynodinium grallator) can be observed. These small differences in palynomorph distribution are probably related to different palaeoenvironmental conditions. The Danian assemblage from the section studied is similar to many assemblages of the same age previously recorded worldwide;

- palynofacies analysis of the section studied shows an abundance of continental organic matter (mainly opaque phytoclasts belonging to the inertinite group, sometimes with small dimensions and rounded shapes), which could suggest an offshore depositional environment of the sedimentary basin. The presence of some oceanic dinocysts (e.g., Impagidinium, Pterodinium) in the Lepşa and Putna-Piatra Uscată formations, supports the same palaeoenvironmental interpretation.

Acknowledgments. The authors would like to thank the two reviewers (P. Gedl, Polish Academy of Sciences and M. Barski, University of Warsaw, Poland) and the Editor in Chief of the journal, T.M. Peryt, for their comments and suggestions that greatly improved the earlier version of this manuscript. $\mathrm{J}$. Zalasiewicz is thanked for linguistic correction of the final version of this text.

\section{REFERENCES}

Alvarez, L.W., Alvarez, W., Asaro, F., Michel, H.V., 1980. Extraterrestrial cause for the Cretaceous-Tertiary extinction. Science, 208: 1095-1108.

Amadori, M.L., Belayouni, H., Guerrera, F., Martín-Martín, M., Martin-Rojas, I., Miclăuş, C., Raffaelli, G., 2012. New data on the Vrancea Nappe (Moldavidian Basin, Outer Carpathian Domain, Romania): paleogeographic and geodynamic reconstructions. International Journal of Earth Sciences, 101: 1599-1623.

Batten, D.J., 1999. Small palynomorphs. In: Fossil Plants and Spores: Modern Techniques (eds. T.P. Jones and N.P. Rowe): 15-19. Geological Society, London.

Benson, D.G., 1976. Dinoflagellate taxonomy and biostratigraphy at the Cretaceous/Tertiary boundary, Round Bay, Maryland. Tulane Studies in Geology and Paleontology, 12: 169-233.

Bojar, A.V., Melinte-Dobrinescu, M.C., Bojar, H.P., 2009. A continuous Cretaceous-Paleocene red-bed section in the Romanian Carpathians. SEPM Special Publication, 91: 121-135.

Brinkhuis, H., Schiøler, P., 1996. Palynology of the Geulhemmerberg Cretaceous/Tertiary boundary section (Limburg, SE Netherlands). Geologie en Mijnbouw, 75: 193-213.

Brinkhuis, H., Zachariasse, J.W., 1988. Dinoflagelltes cysts, sea level changes and planktonic foraminifera across the Cretaceous-Tertiary boundary at El Haria, northwest Tunisia. Marine Micropaleontology, 13: 153-191.
Brinkhuis, H., Bujak, J.P., Smit, J., Versteegh, G.J.M., Visscher, H., 1998. Dinoflagellate based sea surface temperature reconstructions across the Cretaceous-Tertiary boundary. Palaeogeography, Palaeoclimatology, Palaeoecology, 141: 67-83.

Carvalho, M.A., Mendonça Filho, J.G., Menezes, T.R., 2006. Palynofacies and sequence stratigraphy of the Aptian-Albian of the Sergipe Basin, Brazil. Sedimentary Geology, 192: 57-74.

Carvalho, M.A., Ramos, R.R.C., Crud, M.B., Witovisk, L., Kellner, A.W.A., Silva, H.P., Grillo, O.N., Riff, D., Romano, P.S.R., 2013. Palynofacies as indicators of paleoenvironmental changes in a Cretaceous succession from the Larsen Basin, James Ross Island, Antarctica. Sedimentary Geology, 295: 53-66.

Courtillot, V., 1990. Deccan volcanism at the Cretaceous-Tertiary boundary: post climate crisis as a key to the future? Palaeogeography, Palaeoclimatology, Palaeoecology, 189: 291-299.

Courtillot, V., Besse, J., Vandamme, D., Jaeger, J.J., Montigny, R., 1986. Deccan trap volcanism as a cause of biologic extinctions at the Cretaceous-Tertiary boundary? Comptes Rendus de l'Académie des Sciences de Paris, 303: 863-868.

De Coninck, J.D., Smit, J., 1982. Marine organic-walled microfossils at the Cretaceous/Tertiary boundary in the Barranco del Gredero (S.E. Spain). Geologie en Mijnbouw, 61: 173-178.

Drugg, W.S., 1967. Palynology of the Upper Moreno Formation (Late Cretaceous-Paleocene) Escarpado Canyon, California. Palaeontographica, Abteilung B, 120: 1-71. 
Duringer, P., Doubinger, J., 1985. La palynologie: un outil de characterisation des faciès marins et continentaux à la limite Muschelkalk supérieur-Lettenkohle. Science Géologie Bulletin, 38: 19-34.

Egger, H., Mohamed, O., 2010. A slope-basin model for early Paleogene deep-water sedimentation (Achthal Formation nov. nom.) at the Tethyan continental margin (Ultrahelvetic realm) of the European Plate (Eastern Alps, Germany). Austrian Journal of Earth Sciences, 103: 121-137.

Federova, V.A., 1977. The significance of the combined use of microphytoplankton, spores, and pollen for differentiation of multi-facies sediments (in Russian). Trudy VNIGRI, 398: 70-88.

Fensome, R.A., MacRae, R.A., Williams, G.L., 2008. DINOFLAJ2, Version 1. American Association of Stratigraphic Palynologists, Data Series no. 1. http://dinoflaj.smu.ca/wiki/Main Page

Firth, J.V., 1987. Dinoflagellate biostratigraphy of the Maastrichtian to Danian interval in the U.S. Geological Survey Albany core, Georgia, U.S.A. Palynology, 11: 199-216.

Gedl, P., 2004. Dinoflagellate cyst record of the deep-sea Cretaceous-Tertiary boundary at Uzgrun, Carpathian Mountains, Czech Republic. Geological Society Special Publications, 230: 257-273.

Grasu, C., Catană, C., Grinea, D., 1988. Carpathian flysch. Petrography and economic considerations (in Romanian). Editura Tehnică, Bucureşti.

Guédé, K.É., Slimani, H., Louwye, S., Asebriy, L., Toufiq, A., Ahmamou, M., El Amrani, El Hassani, I.E., Zeli Bruno Digbehi, Z.B., 2014. Organic-walled dinoflagellate cysts from the Upper Cretaceous-lower Paleocene succession in the western External Rif, Morocco: new species and new biostratigraphic results. Geobios, 47: 291-304.

Guerrera, F., Martín Martín, M., Martín-Pérez, J.A., Martín-Rojas, I., Miclăuş, C., Serrano, F., 2012. Tectonic control on the sedimentary record of the central Moldavidian Basin (Eastern Carpathians, Romania). Geologica Carpathica, 63: 463-479.

Habib, D., 1982. Sedimentary supply origin of Cretaceous black-shales. In: Nature and Origin of Cretaceous Carbon-rich Facies (eds. S.O. Schlanger and M.B. Cita): 113-127. Academic Press, London.

Habib, D., Olsson, R.K., Liu, C., Moshkovitz, S., 1996. High resolution biostratigraphy of sea level low, biotic extinction, and chaotic sedimentation at the Cretaceous/Tertiary boundary in Alabama, north of the Chicxulub crater. GSA Special Paper, 307: 243-252.

Hansen, J.M., 1977. Dinoflagellate stratigraphy and echinoid distribution in Upper Maastrichtian and Danian deposits from Denmark. Bulletin of Geological Society of Denmark, 26: 1-26.

Hardenbol, J., Thierry, J., Farley, M.B., Jacquin, T., de Graciansky, P.C., Vail, P.R., 1998. Mesozoic and Cenozoic sequence chronostratigraphic framework of European basins. SEPM Special Publication, 60: 3-13.

Hultberg, S.U., 1985. Systematic paleontology. In: Dinoflagellate Studies of the Upper Maastrichtian and Danian in Southern Scandinavia (ed. S.U. Hultberg): 104-189. Ph.D thesis, Department of Geology, University of Stockholm, Stockholm, Sweden.

Ion, J., Antonescu, E., Micu, M., 1982. On the Paleocene of the Bistrita Half-window (East Carpathians). Dări de seamă ale şedințelor, Institutul Geologic şi Geofizică, 69: 117-136.

Ionesi, L., 1966. Contributions on the Cretaceous-Paleogene boundary from external flysch zone of the Eastern Carpathians (in Romanian). Analele Știintifice ale Universității "Al. I. Cuza" laşi, sect. Ilb, Geologie-Geografie, 12: 81-90.

Ionesi, L., 1975. Limite Maestrichtien-Paléocène et Cuisien nummulitique dans le flysch de Bucovine. 14-th European Micropaleontological Colloquium, Micropaleontological Guide to the Mesozoic and Tertiary of the Romanian Carpathians, Published by the Institute of Geology and Geophysics, Bucharest: 145-150.

Keller, G., 2008. Cretaceous climate, volcanism, impacts, and biotic effects. Cretaceous Research, 29: 754-771.

Keller, G., Sahni, A., Bajpai, S., 2009. Deccan volcanism, the K-T mass extinction and dinosaurs. Journal of Biosciences, 34: 709-728.
Machalski, M., Vellekoop, J., Dubicka, Z., Peryt, D., Harasimiuk, M., 2016. Late Maastrichtian cephalopods, dinoflagellate cysts and foraminifera from the Cretaceous-Paleogene succession at Lechówka, southeast Poland: stratigraphic and environmental implications. Cretaceous Research, 57: 208-227.

M'Hamdi, A., Slimani, H., Ben Ismail-Lattrache, K., Soussi, M., 2013. Biostratigraphie des kystes de dinoflagellés de la limite Crétacé-Paléogène à Ellès, Tunisie. Revue de Micropaléontologie, 56: 27-42.

Melinte, M.C., Jipa, D., 2005. Campanian-Maastrichtian marine red beds in Romania: biostratigraphic and genetic significance. Cretaceous Research, 26: 39-46.

Mendonça Filho, J.G., Carvalho, M.A., Menezes, T.R., 2002. Palinofácies. In: Técnicas e Procedimentos para o Trabalho com Fósseis e Formas Modernas Comparativas (ed. T.L. Dutra): 20-24. Unisinos, São Leopoldo.

Micu, M., 1976. Geological map of Romania (1:50 000 scale), 48b sheet, Piatra Neamț (in Romanian). Institutul de Geologie şi Geofizică, Bucureşti.

Mohamed, O., Wagreich, M., 2013. Organic-walled dinoflagellate cyst biostratigraphy of the Well Höflein 6 in the Cretaceous-Paleogene Rhenodanubian Flysch Zone (Vienna Basin, Austria). Geologica Carpathica, 64: 209-230.

Mohamed, O., Piller, W.E., Egger, H., 2012. The dinocyst record across the Cretaceous-Palaeogene boundary of a bathyal midlatitude Tethyan setting: Gosau Group, Gams Basin, Austria. Cretaceous Research, 35: 143-168.

Mohamed, O., Piller, W.E., Egger, H., 2013. Dinoflagellate cysts and palynofacies across the Cretaceous/Palaeogene boundary at the Neritic Waidach Section (Eastern Alps, Austria). Review of Palaeobotany and Palynology, 190: 85-103.

Moshkovitz, S., Habib, D., 1993. Calcareous nannofossil and dinoflagellate stratigraphy of the Cretaceous/Tertiary boundary, Alabama and Georgia. Micropaleontology, 39: 167-191.

Nøhr-Hansen, H., 2012. Palynostratigraphy of the Cretaceous-lower Palaeogene sedimentary succession in the Kangerlussuaq Basin, southern East Greenland. Review of Palaeobotany and Palynology, 178: 59-90.

Olaru, L., 1978. Research on the stratigraphic distribution of microflora in the Paleogene flysch between Bistrița and Trotuş Valleys (In Romanian). Institut de Géologie et de Géophysique, Mémoires, 27: 5-111.

Paul, C.R.C., 2005. Interpreting bioevents: what exactly did happen to planktonic foraminifers across the Cretaceous-Tertiary boundary? Palaeogeography, Palaeoclimatology, Palaeoecology, 224: 291-310.

Pellaton, C., Gorin, G.E., 2005. The Miocene New Jersey passive margin as a model for the distribution of sedimentary organic matter in siliciclastic deposits. Journal of Sedimentary Research, 75: 1011-1027.

Roncaglia, L., Corradini, D., 1997a. Upper Campanian to Maastrichtian dinoflagellate zonation in northern Apennines, Italy. Newsletters on Stratigraphy, 35: 29-57.

Roncaglia, L., Corradini, D., 1997b. Correlation of key dinoflagellate events with calcareous nannoplankton and planktonic foraminiferal zones in the Solignano Formation (Maastrichtian, Late Cretaceous) northern Apennines, Italy. Review of Palaeobotany and Palynology, 97: 177-196.

Săndulescu, M., 1984. Geotectonics of Romania (in Romanian). Editura Tehnică, Bucureşti.

Schiøler, P., Wilson, G.J., 1993. Maastrichtian dinoflagellate zonation in the Dan Field, Danish North Sea. Review of Palaeobotany and Palynology, 78: 321-351.

Schiøler, P., Brinkhuis, H., Roncaglia, L., Wilson, G.J., 1997. Dinoflagellate biostratigraphy and sequence stratigraphy of the type Maastrichtian (Upper Cretaceous), Enci Quarry, The Netherlands. Marine Micropaleontology, 31: 65-95.

Skupien, P., Mohamed, O., 2008. Campanian to Maastrichtian palynofacies and dinoflagellate cysts of the Silesian Unit, Outer Western Carpathians, Czech Republic. Bulletin of Geosciences, 83: $207-224$. 
Slimani, H., 2000. Nouvelle zonation aux kystes de dinoflagellés du Campanien au Danien dans le nord et l'est de la Belgique et dans le sud-est des Pays-Bas. Memoirs of the Geological Survey of Belgium, 46: 1-88.

Slimani, H., 2001. Les kystes de dinoflagellés du Campanien au Danien dans la région de Maastricht (Belgique et Pays-Bas) et de Turnhout (Belgique): biozonation et corrélation avec d'autres régions en Europe occidentale. Geologica et Palaeontologica, 35: 161-201.

Slimani, H., Toufiq, A., 2013. A Cretaceous-Palaeogene boundary geological site, revealed by planktic foraminifera and dinoflagellate cysts, at Ouled Haddou, eastern external Rif Chain, Morocco. Journal of African Earth Sciences, 88: 38-52.

Slimani, H., Louwye, S., Toufiq, A., Verniers, J., De Conink, J., 2008. New dinoflagellate cyst species from Cretaceous/Palaeogene boundary deposits at Ouled Haddou, south-eastern Rif, Morocco. Cretaceous Research, 29: 329-344.

Slimani, H., Louwye, S., Toufiq, A., 2010. Dinoflagellate cysts from the Cretaceous-Palaeogene boundary at Ouled Haddou, southeastern Rif, Morocco: biostratigraphy, paleoenvironments and paleobiogeography. Palynology, 34: 90-124.

Slimani, H., Louwye, S., Dusar, M., Lagrou, D., 2011. Connecting the Chalk Group of the Campinen Basin to the dinoflagellate cyst biostratigraphy of the Campanian to Danian in the borehole Meer (northern Belgium). Netherlands Journal of Geosciences, 90: 129-164.

Slimani, H., Guédé, K.E., Williams, G.L., Asebriy, L., Ahmamou, M., 2016. Campanian to Eocene dinoflagellate cyst biostratigraphy from the Tahar and Sekada sections at Arba Ayacha western External Rif, Morocco. Review of Palaeobotany and Palynology, 228: 26-46.

Sluijs, A., Pross, J., Brinkhuis, H., 2005. From greenhouse to icehouse; organic-walled dinoflagellate cysts as paleoenvironmental indicators in the Paleogene. Earth-Science Reviews, 68 281-315.

Steffen, D., Gorin, G., 1993. Palynofacies of the Upper Tithonian-Berriasian deep-sea carbonates in the Vocotian Trough (SE France). Bulletin Centres Recheches Exploration-Prodution Elf Aquitaine, 17: 235-247.
Torricelli, S., Amore, M.R., 2003. Dinoflagellate cysts and calcareous nannofossils from the Upper Cretaceous Saraceno Formation (Calabria, Italy): implications about the history of the liguride complex. Revista Italiana di Paleontologia e Stratigrafia, 109 499-516.

Twitchett, R.J., 2006. The paleoclimatology, paleoecology and paleoenvironmental analysis of mass extinction events. Palaeogeography, Palaeoclimatology, Palaeoecology, 232: 190-213.

Tyson, R.V., 1995. Sedimentary Organic Matter: Organic Facies and Palynofacies. Chapman and Hall, London.

Țabără, D., 2014. Palynology, palynofacies and organic geochemistry on the Lower Cretaceous succession (Audia Formation) from Eastern Carpathians, Romania. Carpathian Journal of Earth and Environmental Sciences, 9: 83-91.

Tabără, D., Pacton, M., Makou, M., Chirilă, G., 2015. Palynofacies and geochemical analysis of Oligo-Miocene bituminous rocks from the Moldavidian Domain (Eastern Carpathians, Romania) Implications for petroleum exploration. Review of Palaeobotany and Palynology, 216: 101-122.

Vasilyeva, O., Musatov, V., 2012. The Paleogene dinoflagellate cyst and nannoplankton biostratigraphy of the Caspian Depression. In: Stratigraphic Analysis of Layered Deposits (ed. Ö. Elitok): 161-194. InTech.

Williams, G.L., Stover, L.E., Kidson, E.J., 1993. Morphology and stratigraphic ranges of selected Mesozoic-Cenozoic dinoflagellate taxa in the Northern Hemisphere. Geological Survey of Canada Paper, 92-10.

Williams, G.L., Brinkhuis, H., Pearce, M.A., Fensome, R.A. Weegink, J.W., 2004. Southern Ocean and global dinoflagellate cyst events compared: index events for the late Cretaceouse-Neogene. In: Proceedings of the Ocean Drilling Program, Scientific Results, 189: 1-98.

Willumsen, P.S., 2004. Two new species of the dinoflagellate cyst genus Carpatella Grigorovich 1969 from the Cretaceous-Tertiary transition in New Zealand. Journal of Micropalaeontology, 23: 119-125.

Willumsen, P.S., 2011. Maastrichtian to Paleocene dinocysts from the Clarence Valley, South Island, New Zealand. Alcheringa: an Australasian Journal of Palaeontology, 35: 199-240.

\title{
APPENDIX 1
}

\section{Checklist of palynomorph taxa mentioned in the text in alphabetic order. The references to dinocyst species' authors are given by Fensome et al. (2008). Some species listed in this appendix are presented in Figures 3 and 4}

\author{
Dinoflagellate cysts \\ Achomosphaera alcicornu (Eisenack, 1954) Davey and Williams, 1966 (Fig. 30) \\ Achomosphaera ramulifera (Deflandre, 1937) Evitt, 1963 (Fig. 3R) \\ Achomosphaera regiensis Corradini, 1973 (Fig. 4A) \\ Achomosphaera sagena Davey and Williams, 1966 \\ Areoligera senonensis Lejeune-Carpentier, 1938 (Fig. 4B) \\ Batiacasphaera rifensis Slimani, 2008 \\ Cerodinium diebelii (Alberti, 1959) Lentin and Williams, 1987 (Fig. 3M) \\ Cerodinium speciosum (Alberti, 1959) Lentin and Williams, 1987 (Fig. 4D) \\ Cordosphaeridium exilimurum Davey and Williams, 1966 \\ Cordosphaeridium fibrospinosum Davey and Williams, 1966 (Fig. 3S) \\ Cribroperidinium cf. edwardsii (Cookson and Eisenack, 1958) Davey, 1969 \\ Cribroperidinium wetzelii (Lejeune-Carpentier, 1939) Helenes, 1984 (Fig. 4I) \\ Deflandrea galeata (Lejeune-Carpentier, 1942) Lentin and Williams, 1973 (Fig. 3G) \\ Eisenackia circumtabulata Drugg, 1967 (Fig. 3F) \\ Exochosphaeridium cf. majus (Lejeune-Carpentier, 1940) Peyrot, 2011 \\ Fibrocysta axialis (Eisenack, 1965) Stover and Evitt, 1978 \\ Glaphyrocysta perforata Hultberg and Malmgren, 1985 (Fig. 3K) \\ Hafniasphaera septata (Cookson and Eisenack, 1967) Hansen, 1977 \\ Hystrichokolpoma bulbosum subsp. bulbosum (Ehrenberg, 1838) Morgenroth, 1968 (Fig. 3C)
}


Hystrichodinium cf. pulchrum Deflandre, 1935

Hystrichosphaeridium recurvatum (White, 1842) Lejeune-Carpentier, 1940

Hystrichosphaeridium salpingophorum Deflandre, 1935

Hystrichosphaeridium tubiferum (Ehrenberg, 1838) Deflandre, 1937 (Fig. 3N)

Impagidinium sp.

Impletosphaeridium sp.

Impletosphaeridium? clavulum Davey, 1969

Kleithriasphaeridium cf. loffrense Davey and Verdier, 1976

Kleithriasphaeridium truncatum (Benson, 1976) Stover and Evitt, 1978

Lingulodinium sp.

Manumiella seelandica (Lange, 1969) Bujak and Davies, 1983 (Fig. 3H)

Muratodinium fimbriatum (Cookson and Eisenack, 1967) Drugg, 1970 (Fig. 3J)

Oligosphaeridium buciniferum Corradini, 1973 (Fig. 4E)

Oligosphaeridium complex (White, 1842) Davey and Williams, 1966 (Fig. 3P)

Oligosphaeridium pulcherrimum (Deflandre and Cookson, 1955) Davey and Williams, 1966

Operculodinium centrocarpum (Deflandre and Cookson, 1955) Wall, 1967

Operculodinium corradinii Slimani, 1994 (Fig. 4F)

Palaeocystodinium cf. golzowense Alberti, 1961

Palaeoperidinium pyrophorum (Ehrenberg, 1838 ex Wetzel, 1933) Sarjeant, 1967 (Fig. 4G)

Palynodinium cf. grallator Gocht, 1970

Pentadinium sp. A (Fig. 4C)

Phelodinium magnificum (Stanley, 1965) Stover and Evitt, 1978

Protoellipsodinium cf. clavulum Davey and Verdier, 1974

Pterodinium cingulatum (Wetzel, 1933) Below, 1981

Pterodinum cretaceum Slimani, 2008 (Fig. 3A)

Rottnestia wetzelii subsp. wetzelii (Deflandre, 1937) Slimani, 1994 (Fig. 3I)

Senoniasphaera cf. rotundata Clarke and Verdier, 1967

Senoniasphaera inornata (Drugg, 1970) Stover and Evitt, 1978 (Fig. 3E)

Spiniferella cornuta subsp. cornuta (Gerlach, 1961) Stover and Hardenbol, 1994 (Fig. 4H)

Spiniferites multibrevis (Davey and Williams, 1966) Below, 1982

Spiniferites ramosus (Ehrenberg, 1838) Mantell, 1854 (Fig. 3T)

Spiniferites sp.

Systematophora sp.

Tanyosphaeridium xanthiopyxides (Wetzel, 1933) Stover and Evitt, 1978

Tectatodinium rugulatum (Hansen, 1977) McMinn, 1988 (Fig. 3D)

Trithyrodinium evittii Drugg, 1967

Xenascus sp. (Fig. 3L)

Xenicodinium delicatum Hultberg, 1985 (Fig. 3Q)

Xenicodinium lubricum Morgenroth, 1968 (Fig. 3B)

\section{Acritarcha}

Micrhystridium fragile Deflandre 1948

\section{Pteridophyta}

Baculatisporites sp.

Deltoidospora psilostomata Rouse, 1959

Deltoidospora toralis (Leschik, 1955) Lund, 1977

Deltoidospora sp.

Gleicheniidites senonicus Ross, 1949

Triplanosporites sp.

\section{Gymnospermatophyta}

Araucariacites sp.

Cycadopites sp.

Ephedripites sp.

Pinuspollenites sp.

Podocarpidites sp. 